\title{
A Ten-Year History of the Demography and Productivity of an Arctic Wolf Pack
}

\author{
L. DAVID MECH ${ }^{1}$
}

\author{
(Received 22 December 1994; accepted in revised form 4 April 1995)
}

\begin{abstract}
A pack of two to eight adult wolves (Canis lupus arctos) and their pups was observed during ten summers (1986-95) on Ellesmere Island, Northwest Territories, Canada. The author habituated the wolf pack to his presence in the first summer and reinforced the habituation each summer thereafter. The first alpha female produced four to six pups each year between 1986 and 1989. However, her daughter, who succeeded her as the alpha female, produced only one to three pups each year between 1990 and 1992 and in 1994, and apparently did not whelp in 1993 or in 1995. The tenure of the first alpha male was at least two years, and his successor was alpha male for the remaining eight years of the study. The wolf pack was characterized by highly variable annual productivity. The second alpha male-and-female breeding pair likely was an older brother and a younger sister. Early survival of wolf pups was high and constant, with all pups surviving through August of their first year. The pack's demography was consistent with what is known for wolf packs in other regions of North America, but its productivity was more typical of arctic packs.
\end{abstract}

Key words: wolf, Canis lupus, productivity, demography, breeding tenure, survival

RÉSUMÉ. On a observé une bande comprenant de deux à huit loups adultes (Canis lupus arctos) et leurs louveteaux au cours de dix étés (1986-95), dans l'île d'Ellesmere située dans les Territoires du Nord-Ouest au Canada. L'auteur a accoutumé la bande à sa présence durant le premier été et a renforcé l' accoutumance durant chaque été subséquent. La première femelle alpha a produit de quatre à six louveteaux chaque année entre 1986 et 1989. Cependant, sa fille, qui lui a succédé en tant que femelle alpha, a produit seulement de un à trois louveteaux chaque année entre 1990 et 1992 et en 1994, et n'a apparemment pas mis bas en 1993 ni en 1995. Le premier mâle alpha a conservé son statut au moins deux ans, et son successeur a été le mâle alpha durant les huit autres années de l'étude. La bande de loups était caractérisée par une productivité annuelle extrêmement variable. Le deuxième couple reproducteur mâle et femelle alpha était probablement constitué d'un frère et de sa soeur plus jeune. La survie précoce des louveteaux était élevée et constante, tous les louveteaux étant toujours en vie à la fin du mois d'août de leur première année. La démographie de la bande s'accordait avec ce que l'on connaît des bandes de loups dans d'autres régions de l'Amérique du Nord, mais sa productivité était plus typique des bandes arctiques.

Mots clés: loup, Canis lupus, productivité, démographie, statut de reproducteur, survie

Traduit pour la revue Arctic par Nésida Loyer.

\section{INTRODUCTION}

Wolves (Canis lupus) are long-lived animals (Mech, 1988a). However, because they are difficult to study (Mech, 1974; in press), there is little long-term demographic and productivity information about individuals or their packs. An eight-year demographic description of a pack of radio-tagged wolves in the Superior National Forest of Minnesota seems to be the sole record available (Mech and Hertel, 1983) except for general information about certain packs or individuals on Isle Royale, Michigan (Peterson, 1977; Peterson and Page, 1988).

The present study was conducted during the summers from 1986 to 1995 on Ellesmere Island, Northwest Territories, Canada $\left(80^{\circ} \mathrm{N}, 86^{\circ} \mathrm{W}\right)$. There, wolves prey on arctic hares (Lepus arcticus), muskoxen (Ovibos moschatus), and Peary caribou (Rangifer tarandus pearyi) (Mech 1988b).

During 1986, I habituated a pack of wolves to my presence and reinforced the habituation each summer (Mech, 1988b). The wolf pack frequented the same area each year and generally used the same den (Mech and Packard, 1990) or nearby dens (Mech, 1993) each summer. The habituation allowed me to remain with the wolves each day and observe them regularly from distances as close as one metre. I usually began observing the pack each year between 14 and 28 June when the pups were about 10-25 days old, and ended observations in early August.

Individual wolves were recognized on the basis of gender (from urination posture), behavior toward me, presence or absence of dark-tinged fur on the back, and such individual features as a missing tooth, ear notch, and scars. Although not all of the individuals in the study were recognizable by single definitive features, combinations of characteristics appeared to be definitive.

None of the pups from a given year was individually recognizable as a specific pup or as a specific yearling the following year, but the assumption was made that all apparent yearlings were the pack's pups from the previous year. This assumption was supported by the fact that all such yearlings

${ }^{1}$ U.S. National Biological Service, Patuxent Environmental Science Center, Laurel, Maryland 20708, U.S.A.; mailing address: North Central Forest Experiment Station, 1992 Folwell Ave., St. Paul, Minnesota 55108, U.S.A.

(C) The Arctic Institute of North America 
demonstrated the habituation to me resulting from their habituation as pups the previous year. In three observations involving 10 individual wolves not from the habituated pack, the animals did not demonstrate habituation; instead, they failed to let me approach closely and ran off.

The study pack consisted of $2-8$ adults and yearlings each summer, including an alpha pair (Table 1). Besides the alpha pair, five adults ("auxiliaries") were present during 1986 and 1987 and were assumed to be previous offspring of the alpha pair. No auxiliary remained with the pack after 1987 except a male, "Left Shoulder," which became alpha male in 1988. In later years, no auxiliary except each of two females remained with the alpha pair for more than three summers after its birth year (Table 1). "Whitey," one of the auxiliaries that remained, became the alpha female. "Mom," the other auxiliary, was the breeder from 1986 through 1989, and when post-reproductive, was the only wolf that remained with the pack as a mature non-alpha animal. This implies that the other auxiliaries dispersed, similarly to wolves elsewhere (Fritts and Mech, 1981; Van Ballenberghe, 1983; Peterson et al., 1984; Messier, 1985; Fuller, 1989; Gese and Mech, 1991).

In 1988, none of the 1986 or 1987 auxiliaries was present, but two other individuals, Whitey and "Gray Back," accompanied the alpha pair. They were assumed to be pups of the previous year because they were habituated. Whitey and Gray Back were also present in 1989, along with the alpha pair and the four 1988 pups.

When I arrived each year, the study pack was tending pups in the same "traditional" den during five of the eight years they had pups; in 1990, it moved its only pup there from a pit den $2.8 \mathrm{~km}$ away, and in 1991 it used dens within $2.8 \mathrm{~km}$ of the traditional den (Mech, 1993). During 1989, the pack denned $24 \mathrm{~km}$ from the traditional den, but this was the first year after a photographer had crawled into the traditional den and filmed the pups.

During the two summers when the pack was not tending pups when I arrived, the appearance of the abdomen of the alpha female indicated that she had not nursed pups. Furthermore, during 1993 there was no fresh digging at the traditional den or at any of the alternate or subsidiary dens nearby. Thus the pack probably had not produced pups that year. In 1995, there was fresh digging but no pups.

Two females produced pups during the study: Mom and her daughter Whitey. Mom produced four to six pups each year from 1986 through 1989 (Table 2). Of Mom's pups, only the 1988 litter of four could be sexed (by urination posture), and the ratio was three males to one female. All of Mom's pups observed each year in early summer survived at least through early August. Her 1988 litter of four survived at least through August 1989.

Mom remained with the pack but produced no more pups after 1989. Assuming that in 1986 Mom was at least three years old (the age at which Whitey began producing pups) and probably more like five years old judging from her general appearance and behavior, she must have been seven to nine years old when she stopped reproducing, and she could have been much older. Reproductive ability in wild
TABLE 1. Tenures of individual wolves of the study pack on Ellesmere Island, N.W.T. during summer.

\begin{tabular}{|c|c|c|c|c|c|c|c|c|c|c|c|}
\hline Pack Members & Sex & 198 & & 9 & & 195 & & & 94 & 95 & 1995 \\
\hline Mom & $\mathrm{F}$ & $\underline{X}^{1}$ & $\underline{X}$ & $\underline{X}$ & $\underline{X}$ & $\mathrm{X}$ & $X$ & - & - & - & - \\
\hline Alpha Male & M & $\underline{x}$ & $\underline{\bar{X}}$ & - & - & - & - & - & - & - & - \\
\hline Left Shoulder & M & $\overline{\mathrm{X}}$ & $\bar{X}$ & $\underline{X}$ & $\underline{X}$ & $\underline{X}$ & $\underline{X}$ & $\underline{X}$ & $\mathrm{X}$ & $\underline{X}$ & $\mathrm{X}$ \\
\hline Mid Back & $\mathrm{F}$ & $X$ & $\mathrm{X}$ & - & - & - & - & - & - & - & - \\
\hline Lone Ranger & M & $\mathrm{X}$ & $X$ & - & - & - & - & - & - & - & - \\
\hline Shaggy & $\mathrm{F}$ & $X$ & $X$ & - & - & - & - & - & - & - & - \\
\hline Scruffy & $?$ & $X$ & $\mathrm{X}$ & - & - & - & - & - & - & - & - \\
\hline Whitey & $\mathrm{F}$ & - & $--^{2}$ & $\mathrm{X}$ & $\mathrm{X}$ & $\underline{X}$ & $\underline{X}$ & $\underline{X}$ & $\mathrm{X}$ & $\underline{X}$ & $\mathrm{X}$ \\
\hline Gray Back & $\mathrm{M}$ & - & $-^{2}$ & $\mathrm{X}$ & $\mathrm{X}$ & - & - & - & - & - & - \\
\hline Scar Nose & M & - & - & $-^{2}$ & $\mathrm{X}$ & - & - & - & - & - & - \\
\hline Little Girl & $\mathrm{F}$ & - & - & $z^{2}$ & $\mathrm{X}$ & - & - & - & - & - & - \\
\hline No Name & M & - & - & $-^{2}$ & $\mathrm{X}$ & - & - & - & - & - & - \\
\hline No Name & $\mathrm{M}$ & - & - & $--^{2}$ & $\mathrm{X}$ & - & - & - & - & - & - \\
\hline Explorer & $\mathrm{F}$ & - & - & - & - & - & - & $2^{2}$ & $\mathrm{X}$ & $X$ & - \\
\hline White Face & $\mathrm{F}$ & - & - & - & - & - & - & $-^{2}$ & $\mathrm{X}$ & - & - \\
\hline Gray Back II & M & - & - & - & - & - & - & $--^{2}$ & $\mathrm{X}$ & $\mathrm{X}$ & $X$ \\
\hline Total Adults & & 7 & 7 & 4 & 8 & 3 & 3 & 2 & 5 & 4 & 3 \\
\hline
\end{tabular}

\footnotetext{
${ }^{1}$ Underlining indicates breeder for that year.

${ }^{2}$ Present as a pup but not yet individually recognizable.
}

wolves appears to extend through about 11 years of age (Mech, 1988a).

Whitey was born to Mom in 1987 and was first distinguishable as a yearling because of her pure white coat which no adult female in 1986 or 1987 possessed. After replacing Mom as the breeder in 1990 at age three, she produced a single male pup during her first year, two males the next year, two females and a male the following year, none the fourth year, and a single male again during her fifth year, and no pup during her sixth year (Table 2). All survived through early August of their first year, but only the 1992 litter of three survived through its entire first year (Table 2); the 1994 pup survived at least through October 1994.

Mom helped care for Whitey's pups during 1990 and 1991 but was not seen after that. Whitey had dominated Mom during summer 1989 as evidenced by her dominant posture, her behavior towards Mom, and her raised-leg urination. Whitey continued to dominate Mom in summer 1990 and 1991 when Whitey produced the pups. In 1990, when I arrived and Whitey's single pup was estimated to be 10 days old, Mom and Whitey both attended the den.

However, on the day I arrived in 1991, when Whitey's two pups were estimated to be 10-14 days old, I did not see Mom. Nevertheless, when the pups were about 17 days old on 19 June, Whitey and the alpha male chased a third wolf that could have been Mom from around the den for a distance of at least $2 \mathrm{~km}$. The next day, Mom was seen lying $50 \mathrm{~m}$ from Whitey and the pups. Although Whitey thoroughly dominated and chased Mom several times during the next few days, by 24 June, Mom had reintegrated into the pack. During the rest of the summer, her behavior was similar to that of a regular pack member: she attended the pups and accompanied the alpha pair on hunting trips and when the pair moved the pups.

The pack had two consecutive alpha males during the tenyear study period, "Alpha Male" in 1986 and 1987, and Left 
TABLE 2. Wolf pup production and survival for wolf pack studied on Ellesmere Island, N.W.T.

\begin{tabular}{|c|c|c|c|c|}
\hline \multirow[b]{2}{*}{ Year } & \multicolumn{3}{|c|}{ Pups Produced ${ }^{1}$} & \multirow[b]{2}{*}{ Survival Time $^{2}$} \\
\hline & Males & Females & $?$ & \\
\hline 1986 & - & - & 6 & $\geq 3 \mathrm{mo}$ \\
\hline 1987 & - & - & 5 & $1 \mathrm{M} \geq 2 \mathrm{mo} ; 1 \mathrm{~F} \geq 8 \mathrm{yr}$ \\
\hline 1988 & 3 & 1 & 0 & $\geq 2 \mathrm{mo}$ \\
\hline 1989 & - & - & 4 & $\geq 10 \mathrm{mo}$ \\
\hline 1990 & 1 & 0 & 0 & $6 \mathrm{mo}$ \\
\hline 1991 & 2 & 0 & 0 & $\geq 2 \mathrm{mo}$ \\
\hline 1992 & 1 & 2 & 0 & $\mathrm{IF} \geq 17 \mathrm{mo} ; 1 \mathrm{~F} \geq 27 \mathrm{mo} ; 1 \mathrm{M} \geq 37 \mathrm{mo}$ \\
\hline 1993 & 0 & 0 & 0 & - \\
\hline 1994 & 1 & 0 & 0 & $\geq 5 \mathrm{mo}$ \\
\hline 1995 & 0 & 0 & 0 & - \\
\hline
\end{tabular}

${ }^{1}$ Produced by Mom during 1986-89 and by Whitey during 1990-95.

${ }^{2}$ Survival beyond August each year determined through observations of government weather station personnel.

Shoulder from 1988 through 1995. Left Shoulder was believed to be one of the 1986 pack members judged to be two years old at that time. This animal in 1986 had a wound behind his left shoulder blade about $10 \mathrm{~cm}$ in diameter $(\mathrm{Mech}$, 1988b). In 1987, the scar was still apparent through the fur. In 1988, Alpha Male, who had a lower incisor missing, was absent, and I and another worker who had observed the wolves in 1986 and 1987 independently judged that the alpha male in 1988 was Left Shoulder.

The origin of Left Shoulder is unknown, but if he was the offspring of Mom and Alpha Male, Whitey would have been his younger sister. Thus his mating from 1988 through 1994 with Whitey would have constituted inbreeding. If Left Shoulder was at least 2 years old in 1986, then he was at least 4 years old when assuming the alpha male role in 1988 and at least 11 years old in 1995. Nevertheless, in 1995 his canine teeth still appeared quite sharp.

\section{DISCUSSION}

Whitey's productivity was low compared to that of her mother and to that of wolves in lower latitudes, which usually average litter sizes of five to six (Mech, 1970). This could be related to inbreeding depression (Laikre and Ryman, 1991) if Whitey and Left Shoulder are siblings. However, at the high latitude where this pack resided, average litter sizes appear to be about two to three (Marquard-Petersen, 1994), so Whitey's production may not be unusual.

The cause of Whitey's lack of reproduction in 1993 may be related to the fact that all three of her 1992 pups survived into 1993. Feeding three pups from birth through the breeding season may have left Whitey with too few body reserves to ovulate, conceive, or carry pups to term. During summer 1993, both Whitey and Left Shoulder regularly delivered food to their three yearlings, and the yearlings often remained at rendezvous sites as most pups do through their first five months. Such an explanation would not account for Whitey's barrenness in 1995, however, for 1994's pup was not present then. Also notable is the fact that neither Whitey's 1990 pup nor her two 1991 pups survived beyond autumn, and probably her 1994 pup failed to survive.

The data obtained in this study are consistent with what is known about wolf pack demography from other areas (Fritts and Mech, 1981; Mech and Hertel, 1983; Peterson et al., 1984; Fuller, 1989; Gese and Mech, 1991; Meier et al., in press), except for Whitey's low productivity. However, this study extends that information in several ways, demonstrating the breeding tenures, productivity, and intrapack relations of individual wolves, documenting the high survival of young pups through the summer, and questioning the cause of one female's relatively low productivity and survival of pups.

\section{ACKNOWLEDGEMENTS}

This project was supported by the National Geographic Society, the United States Fish and Wildlife Service, the United States National Biological Service, and the United States Department of Agriculture North Central Forest Experiment Station. Logistical help of the Polar Continental Shelf Project, Natural Resources Canada; Atmospheric Environment Services (AES), Environment Canada; and High Arctic International are also greatly appreciated. Permits were granted by the Department of Renewable Resources and the Grise Fiord Hunter and Trapper Association of the Northwest Territories. The observations of AES personnel during autumn and the logistical help of one or two field assistants each year who accompanied the author during the study are gratefully acknowledged.

\section{REFERENCES}

FRITTS, S.H., and MECH, L.D. 1981. Dynamics, movements and feeding ecology of a newly protected wolf population in northwestern Minnesota. Wildlife Monograph 80:1-79.

FULLER, T.K. 1989. Population dynamics of wolves in NorthCentral Minnesota. Wildlife Monograph 105:1-41.

GESE, E.M., and MECH, L.D. 1991. Dispersal of wolves (Canis lupus) in northeastern Minnesota, 1969-1989. Canadian Journal of Zoology 69(12):2946-2955.

LAIKRE, L., and RYMAN, L. 1991. Inbreeding depression in a captive wolf population. Conservation Biology 5(1):33-40.

MARQUARD-PETERSEN, U. 1994. Dens and summer pack size of Arctic wolves in Hold with Hope, East Greenland. Polar Record 30(172):46-49.

MECH, L.D. 1970. The wolf: The ecology and behavior of an endangered species. New York: Natural History Press, Doubleday Publishing Company.

1974. Current techniques in the study of elusive wilderness carnivores. Proceedings of the Eleventh International Congress of Game Biologists. 315-322.

. 1988a. Longevity in wild wolves. Journal of Mammalogy 69(1):197-198.

1988b. The arctic wolf: Living with the pack. Stillwater, Minnesota: Voyageur Press. 
1993. Resistance of young wolf pups to inclement weather. Journal of Mammalogy 74(2):485-486.

. In press. What more do we need to know about wolves and how do we learn it? In: Carbyn, L.D., Fritts, S.H., and Seip, D.R., eds. Ecology and conservation of wolves in a changing world. Edmonton: Canadian Circumpolar Institute.

MECH, L.D., and HERTEL, H.H. 1983. An eight-year demography of a Minnesota wolf pack. Acta Zoologica Fennica 174:249250.

MECH, L.D., and PACKARD, J.M. 1990. Possible use of wolf (Canis lupus) den over several centuries. Canadian FieldNaturalist 104(3):484-485.

MEIER, T.J., BURCH, J.W., MECH, L.D., and ADAMS, L.G. In press. Pack structure dynamics and genetic relatedness among wolf packs in a naturally regulated population. In: Carbyn, L.D., Fritts, S.H., and Seip, D.R., eds. Ecology and conservation of wolves in a changing world. Edmonton: Canadian Circumpolar Institute.

MESSIER, F. 1985. Solitary living and extra-territorial movements of wolves in relation to social status and prey abundance. Canadian Journal of Zoology 63(2):239-245.

PETERSON, R.O. 1977. Wolf ecology and prey relationships on Isle Royale. U.S. National Park Service Science Monograph Series $11.210 \mathrm{p}$.

PETERSON, R.O., and PAGE, R.E. 1988. The rise and fall of the Isle Royale wolves. Journal of Mammalogy 69(1):89-99.

PETERSON, R.O., WOOLINGTON, J.D., and BAILEY, T.N. 1984. Wolves of the Kenai Peninsula, Alaska. Wildlife Monographs 88.52 p.

VAN BALLENBERGHE, V. 1983. Extraterritorial movements and dispersal of wolves in southcentral Alaska. Journal of Mammalogy 64(1):168-171. 